\section{Chijioke Nwachukwu ${ }^{1}$ Helena Chladkova}

Article info: Received 05.05.2018 Accepted 06.09.2018

UDC - 001.8:35.073.53 DOI - 10.24874/IJQR13.01-05

\title{
FIRM RESOURCES, STRATEGIC ANALYSIS CAPABILITY AND STRATEGIC PERFORMANCE: ORGANISATIONAL STRUCTURE AS MODERATOR
}

\begin{abstract}
Understanding the impact of efficient utilization of firm resources and capabilities is important to achieve and sustain strategic performance. This paper examines firm resources, strategic analysis capability and the moderating role of organisational structure in the relationship between firm resources, strategic analysis capability and strategic performance. The study adopts a survey method to collect data from 105 employees on managerial levels of the four multinational firms operating in the mobile telecommunication sector in Nigeria. The results suggest that human resources, financial resources, strategic analysis capability has a positive and significant relationship with strategic performance. Additionally, organisational structure moderates the relationship between human resources, financial resources, strategic analysis capability and strategic performance. The authors concluded that by recognising the impact of organisational structure on human resources, financial resources and strategic analysis capability, managers/executives can significantly enhance strategic performance.
\end{abstract}

Keywords: Human resources, Financial resources, Strategic performance, Resource-based view, Organisational structure

\section{Introduction}

Although the difficulties and challenges of multinational firms have been explored in the literature and various theoretical underpinnings have been advanced, there still remains more to understand. Most importantly, how human resources, financial resources and strategic analysis capability affects strategic performance of multinational firms has not been essentially examined. Infact, few studies have focused on the relationship between firm resources, strategic analysis and strategic performance of multinational firms operating in the mobile telecommunication sector in Africa and in Nigeria contexts. Indeed, even in the developed markets where some studies have been conducted on multinational firms, few examined, if any, the moderating effects of organizational structure on the strategic performance of multinational firms operating in the mobile telecommunication industry. In the light of resource-based view (RBV), certain types of resources owned and controlled by firms can enable them to achieve sustainable competitive edge, which leads to superior business performance (Wernerfelt, 1984; Barney, 1991). Additionally, firm resources have been

\footnotetext{
1 Corresponding author: Chijioke Nwachukwu

Email: cesogwa@yahoo.com
} 
categorized into tangible resources, (human, financial, organizational and physical), and intangible resources, (reputational, regulatory, social, positional, functional, and cultural). Furthermore, for resources to confer competitive advantage, the resources must be valuable, rare, and hard to copy. Human resources (Rose \& Kumar, 2007; Adner \& Helfat, 2003), and financial resources are more important in achieving and sustaining competitive advantage. Indeed, human resources coordinate other types of resources, whereas the effective and efficient use of financial resources enables firms to acquire other strategic resources or assets. Considering this argument, the authors focus on two tangible resources (namely, human resources and financial resources). The RBV of the firm suggests that certain types of resources owned and controlled by firms have the potential to generate competitive advantage, which eventually leads to superior business performance. Human resources such as top and middle management, administrative and production employees contribute to firm competitive advantage and business performance (Morgan et al., 2004; Datta et al., 2005; Ainuddin et al., 2007). Likewise, financial resources such as cash-inhand, bank deposits and/or savings and financial capital (e.g. stocks and shares) also help to explain the level of firm competitive advantage and performance (Ainuddin et al., 2007; Morgan et al., 2004). Consequently, strategic planners must on a continuous basis evaluate their internal resources and operating environment for possible threats and opportunities to remain competitive. Strategic analysis capability focuses on the ability of firms to assess the quantity and quality of the company's financial, human and physical resources and the external environment of the firm, by collecting information that enable them adapt to changes in their business environment (Adema \& Roehl, 2010; Evans et al., 2003). Empirically, human resources have been found to have positive relationship with firm performance (Morgan et al., 2004; Datta et al., 2005;
Ainuddin et al., 2007; Sorooshian et al., 2010; Ologunde et al., 2015), financial resources and performance (e.g., Othman et al., 2015; Adomako \& Danso, 2014). Most of these studies used financial indicators to measure performance (e.g., Sorooshian et al., 2010; Ologunde et al., 2015). Additionally, the findings into the possible connection between firm resources and strategic analysis capability have not been fully explored in term of their impact on strategic performance. Also, the moderating effect of other variables like organisational structure in the relationship between firm resources, strategic analysis capability and strategic performance is uncertain and relatively unclear (Stefanović et al., 2015). We argue that a contingency approach (Burns \& Stalker, 1961; Lawrence \& Lorsch, 1967) and the analysis of moderating role gives an appropriate theoretical underpinning to explore how organisational structure affect firm resources, strategic analysis capability and strategic performance. Arguably, the relationship between firm resources, strategic analysis capability and strategic performance may be contingent upon a flexible organisational structure. A flexible organisational structure and governance model are important to support the efficient use of human resources, financial resources, and strategic analysis capability of a firm. In the light of this argument, we introduced organisational structure as a moderator in the study. This study focuses on multinational firms operating in the mobile telecommunication industry in Nigeria. There were four firms operating in the mobile telecommunication sector in Nigeria in 2017. The mobile telecommunication sector contributed 9.13 percent to Nigeria's Gross Domestic Product, (GDP) in 2016 (Nigerian Communications Commision, 2017), attracted highest foreign direct investment, consistently created jobs more than any sector in the economy. Investments in the Nigerian fast growing telecommunications sector have been put at $\$ 68$ billion ( $\$ 35$ billion of this comes from Foreign Direct Investments (FDIs) (NCC, 
2017). Due to a dearth of research that examined the subject in the mobile telecommunication firms in the African contexts, especially in Nigeria, this study attempts to fill the gaps in the literature. This study contributes to knowledge by examining the moderating role played by organisational structure in the relationship between firm resources, strategic analysis and strategic performance. Secondly, adds to the limited studies on the direct relationship between firm resources, strategic analysis capability and performance using strategic performance as a performance indicator (Santos \& Brito, 2012) in multinational firms in the emerging market context. In specific terms, this study examines the direct and the moderating effect of organisational structure in the relationship between human resources, financial resources strategic analysis and strategic performance in the Nigerian mobile telecommunications sector. The study uses the theoretical lens of contingency theory (Birkinshaw, Nobel \& Ridderstrale, 2002) and Resource-Based View (RBV) which focuses on leveraging on firms resources and capabilities to achieve competitive advantage (Wernerfelt 1984; Barney 1991).

\section{Review of Literature}

\subsection{Theoretical Framework}

Contingency theory contends that there is no one best way of organizing; contextual factors play a key role in predicting the effectiveness of a given 'structure' (Birkinshaw et al., 2002). Specifically, an alignment between organizational characteristics and contingency factors produces better performance than a misfit. Contingency perspective may be useful to uncover specific effects of firm resources and strategic analysis capability. The effects of firm resources (human resources and financial resource) and strategic analysis capability on strategic performance may be enhanced or restricted, depending on the specific contexts (organizational structure) in which the firm operates. The contingency view has been used in both theoretical and empirical studies, for instance on board roles, board effectiveness and firm performance (Nicholson \& Kiel, 2003), national contexts, and the behavioural approach for boards (Charreaux, 2005), corporate innovation is facilitated in larger firms (Damanpour, 2010). We argue that a contingency approach and the related analysis of moderating effects provide an appropriate theoretical lens to explore how firm resources and strategic analysis capability affect strategic performance. Prior studies have used RBV to explain the competitive value of innovation strategies and business performance (Terziovski, 2010; Cheng et al., 2014; Wang, 2014), strategy formulation process and innovation performance (Nwachukwu, Chladkova \& Olatunji, 2018), human resources and sustainable competitive advantage (Huselid, 1995; Kamoche, 1996). The differences in performance is as a result of a firm possessing valuable, rare and difficult to copy resources that competitors do not have (Wernerfelt, 1984). The resources such as assets, capabilities, attributes, information, organisational processes, knowledge, etc. controlled by firms enable them to develop and implement strategies that enhance their operations (Barney, 1991). Thus, competitive advantage is not just the outcome of competitive behaviour, but it is contingent on strategic resources owned and controlled by a firm. Arguably, in terms of strategic performance, a well managed human resources, financial resources and strategic analysis capability may enhance the firm's capacity to develop new products and services which could lead to improved customer satisfaction, customer patronage and thus contribute positively to strategic performance. Additionally, building strategic analysis capability could help firms to exploit opportunities and/or neutralize threats in their operating business environment, which can contribute to superior strategic performance. 


\subsection{Firm Resources, Capabilities and Business Performance}

In the past, some scholars have explored the link between firm resources and performance (e.g., Pantzalis, 2001). In a globally competitive environment, production innovation, combination and allocation of business resources are the success factors for firms (Teece et al., 1997). The resource-based view focuses on gaining competitive advantages using resources and capabilities. Resources are those intangible and tangible assets connecting the firm in a semipermanent way, whereas capabilities are related to the way of accomplishing different activities, depending on the available resources (Grant, 1991). The value of firm's resources and capabilities depend on context. Therefore, empirical study of the resource-based view must consider resources and capabilities in the industry context where they potentially hold value. The effect of resources and capabilities on performance is determined by two characteristics of the knowledge that drives them: the difficulty that competitors face in copying them (imperfect, imitability) and the difficulty they have in getting them from the market (imperfect mobility) (YuanYao et al., 2009). Thus, in this study, we focused on human resources, financial resources and strategic analysis capability which might have an influence on the strategic performance of multinational firms operating in the Nigerian mobile telecommunication industry.

\subsection{Human Resources and Business Performance}

Human resource (HR) is one of the most important assets that can help firms achieve and sustain competitive advantage. Human resource is a bundle of education, employment or industry experience and other types of experiences that enable firms to deliver superior performance._Barney (1991) opined that human resources consist of the number and characteristics of personnel available to formulate and implement a firm 's strategy. Human resources need to be managed very carefully to ensure that only the best people are selected and exposed to highquality training and development. Highquality human resources and effective HR management could make firms efficient and thus increase their financial performance (Langford \& Male, 2008). Past studies suggest that human resource is a distinctive source of competitive advantage of the firms (e.g. Dunford et al., 2001), people management is a key source for improving employee satisfaction (Nwachukwu \& Chladkova, 2017), firm's strategy and the use of human resources (Lee et al., 2010), human resources and performance (Lee et al., 2010; Ahmad \& Schroeder, 2003), attention to human resource management and financial performance (Sorooshian et al., 2010) strategic HRM, profitability and market share of the SMEs (Ologunde et al., 2015). Shigang \& Guozhi (2016) investigated the relationship between core capability and international performance of Chinese construction firms. It was observed that HR management capability has a significant positive relationship with the performance of Chinese construction firms. Muogbo (2013) found a strong positive correlation between SHRM and performance level of competition in SMEs in Nigeria. In the same direction, Yuan-Yao et al. (2009) found a positive relationship between human resources and performance of Taiwan's IC design industry.

H1: Human resources positively and significantly influence mobile telecommunication firms strategic performance.

\subsection{Financial Resources and Business Performance}

Financial resources capability explains the ability of a firm to use its financial resources to enhance profits (Inmyxai \& Takahashi, 2010). A robust financing strategy that 
supports effective and efficient allocation of financial resources is vital to achieve business success. Access to financial resources enables firms to achieve sustainable growth, performance and as well as develop innovative initiatives. Danso \& Adomako (2014) noted that financial resource is important for the operations of firms. Thus, it is important for firms to implement financial strategies that support the optimization of their financial resources to survive in a competitive and dynamic business environment. Businesses need enough financial capital that can easily be converted into other types of resources (Dollinger, 1999), to support the implementation of internal growth strategies and to gain competitive advantage through superior returns (Barney, 1986). Financial resources of a firm include among others, financial liquidity, operating funds, borrowing capacity and the ability to generate internal funds is crucial for firm survival and profitability. Financial capital availability enables a firm to pursue new strategies, practices and new growth opportunities (Cooper et al., 1994). Indeed, financial resources constraints can hinder the development and introduction of innovative products and services to the market and strategic performance. Additionally, it may be impossible to implement resource-intensive growth strategies, experiment with innovative projects and new strategies in a resourceconstrained environment (Mousa, 2009; Cyert \& March, 1992). Neneh (2016) observed that SME has low levels of financial literacy and availability, financial literacy has a positive impact on SME performance and the relationship is positively moderated by financial capital availability. Shigang \& Guozhi (2016) found that a positive relationship exists between financial capability and performance of Chinese construction firm. Empirically, Othman et al. (2015) observed that the availability of current assets has a significant and positive association with performance as measured by only gross profits. Secondly, the availability of business finance is significantly positively associated to performance as measured by gross profit, net profit and total reserves. Using RBV, Adomako \& Danso (2014) explored the direct relationship between financial literacy and firm performance and the moderating role of resource flexibility and financial capital availability on the relationship between financial literacy and firm performance. The findings indicate that financial literacy is positively related to firm performance, financial capital availability positively moderates the relationship between financial literacy and firm performance, and resources flexibility positively moderates the relationship between financial literacy and firm performance. Similarly, Clarke et al. (2010) find a positive relationship between financial capital and firm performance. Nonetheless, there are very few studies on financial resources performance nexus in Nigeria. In light of previous studies, the authors argue that effective and efficient use of financial resources will have a positive impact on strategic performance.

H2: Financial resources positively influence mobile telecommunication firms strategic performance.

\subsection{Strategic Analysis Capability and Business Performance}

Creating strategic identity and executing strategic analysis is a challenging task during the process of strategy formulation (Nwachukwu et al., 2018). A systematic approach to strategic analysis could enable firms to deal with possible/potential threats and opportunities and thus achieve superior business results. Strategic analysis enables firms to assess their strengths and weaknesses in terms of financial, human, physical resources, company's management and organisational structure, as well as all the conditions and forces that affect its strategic options and define its competitive situation (Pearce II \& Robinson, 2011). Different tools have been proposed for conducting effective 
strategic analysis such as Porter's five forces that shape competition, strength, weaknesses, opportunities, threats (SWOT), value chain analysis (VCA), and product lifecycle (PLC) among others. Porter five forces that shape competition suggests that the state of competition in the industry depends on customer, suppliers, potential entrants, substitute products and competitors. SWOT is a strategic analysis method used to evaluate the internal strengths and weaknesses of a firm and the environmental opportunities, and threats facing that firm. Value chain analysis focuses on how a business creates customer value by examining the contributions of different activities within the business to that value. Product life cycle (PLC) is one way to identify success factors against which executive can evaluate their firm's competencies relative to its key product or products. Strategic planners use PESTE analysis to assess the influence the remote environment exert on their firm's activities. The remote environment comprises factors that are beyond the control of a firm; (1) political/legal, (2) economic, (3) social, (4) technological, (5) ecological. Some empirical studies have shown that strategic/environmental analysis has a positive relationship with performance. Popoola (2000) found that environmental scanning enables banks in Nigeria to gain competitive advantage. Karami (2008) explored the relationship between environmental scanning and growth strategy in the British electronic manufacturing industry. The findings reveal that in today's high levels of competition, and uncertainty, businesses scan the environment to improve their competitiveness. Using the survey method, Okeke et al. (2016) explored the effect of strategic management variables on the performance of small and medium scale enterprises (SMEs) in Nigeria. It was observed that environmental analysis is significantly related to SMEs' performance. Kumar (2015) using correlation analysis found that environmental scanning dimension of strategic planning steps has a significant and positive association with firm performance. Aremu and Oyinloye (2014) examined the impact of strategic management on the performance of five banks in Ilorin Metropolis, Ilorin, Kwara State, Nigeria. The results reveal a positive correlation between environmental scanning and performance of banks in Nigeria. Arguably, for stability in any organisation, executives must constantly evaluate their strategic position in light of the influence from the environment in which they operate. We, therefore, hypothesize that;

H3: Strategic analysis capability is positively related to mobile telecommunication firms strategic performance.

\subsection{Firm Resources, Strategic Capability, Strategic Performance and the Moderating Role of Organisational Structure}

Today's rapidly changing global market require firms to adopt flexible organisational structures and governance models to survive and create value for divergent stakeholders. An organisational structure is the lines of authority and communication between different departments, units, people and processes which facilitates decision-making within the organisation. A number of scholars have found a positive relationship between organisational structure and performance (e.g. Okeke et al., 2016; Nwosu, 2015; Qingmin et al., 2012), market share (Akinyele, 2011), customer perspective and internal process (Awino, 2015). Some other studies found that organisational structure is not positively related to performance (e.g Oyewobi et al., 2013). Robbin \& DeCenzo (2005) contend that the organisation structure performs an important function in the achievement of firm objectives and strategic goals. Arguably, organisation's structure becomes more relevant when it is in harmony with the objective, mission, competitive environment and resources of the organization. Some scholars have argued that organisational structure interacts with a variety of factors to influence organisational 
performance. These factors include organizational size (e.g., Pugh et al., 1969), environmental change (e.g., Lawrence \& Lorsch, 1967), organizational production technology (e.g., Woodward, 1965), and organisational strategy (Chandler, 1962). Structure provides a natural choice to consider in exploring moderating effects (Ambrose \& Schminke. 2003). In this study, we consider organisation structure as an organic environment that is flexible, loose, decentralized, with open and informal communication pattern and appropriate governance model. This type of structure allows employees the flexibility needed to deliver superior performance (Ambrose \& Schminke, 2003). Indeed, it can be argued that efficient allocation and utilisation of human resources, financial resources and strategic analysis capability will contribute to superior strategic performance based on a flexible and robust organisational structure. In light of the above we hypothesize that;

H4: Organisational structure positively moderates the impact of human resources on strategic performance.

H5: Organisational structure positively moderates the impact of financial resources on strategic performance.

H6: Organisational structure positively moderates the impact of strategic analysis capability on strategic performance.

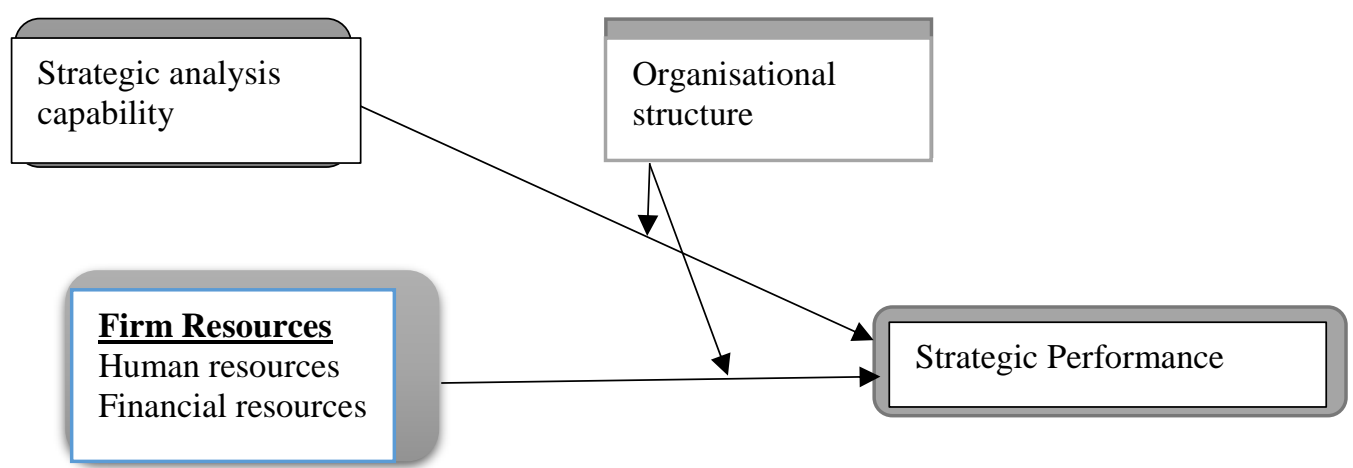

Figure 1. Conceptual model showing the relationship between the research variables Source: Authors work, 2017

\section{Methods}

\subsection{Research questions}

1) What is the relationship between human resources and strategic performance?

2) Is financial resources positively and significantly related to strategic performance?

3) Is there a positive relationship between strategic analysis capability and strategic performance?

4) Is the relationship between human resources and strategic performance stronger, when organisational structure is added as a moderator?

5) Does organisational structure positively moderate the impact of financial resources on strategic performance?

6) Does organisational structure positively moderate the impact of strategic analysis capability on strategic performance?

\subsection{Participants and settings}

The target population of the study is 120 analysts/supervisors, lower, middle and 
senior managers who are responsible for strategic decision-making in the four multinational firms operating in the Nigerian mobile telecommunication sector in 2017. These categories of employees are responsible for developing, implementing and evaluating strategies at corporate, business, and functional levels. Questionnaires were sent to all the 120 employees of the sample firms. The targeted respondents were drawn from sales, marketing, finance/audit, customer service and engineering departments of the sample firms head offices and eight regional offices across the country who are involve in strategic management and decision-making. The sample size of 120 employees is within the recommended sample size for a correlational study (Bryman, 2004).

\subsection{Data collection}

The surveys are useful methods for collecting large quantities of data from respondents (McDaniel et al., 2008) either by means of interview surveys or self-completion questionnaires. This study used a set of questionnaires and secondary data. The questionnaire methods are faster, cheaper and effective means of collecting data. The instrument was designed in three main parts; Part A of the questionnaire collected data on human resources, financial resources, strategic analysis capability and organisational structure. To make processing of the responses easy, we used a five-point scale, from 1 (strongly disagree) to 5 (strongly agree). For human resources, two questions were used to measure whether the firms have the right number of people with the right skills, experience, qualification and competencies to plan, manage and support its strategic initiatives. For financial resources, two questions were used to assess company financial capacity to support its business operations and management commitment to provide financial resources to support strategic initiatives. For strategic analysis capability, five questions were used to assess the company attention to the development of external and internal environment, the company ability to systematically analyse the external and internal environment using robust strategic analysis tools. For organisational structure, two questions were used to assess whether the current structure is flexible and appropriate to support the firm business activities and if current governance model is effective to support the strategic initiatives. Part B was used to collect data about the respondents. Part $\mathrm{C}$ measure strategic performance using four items adapted from Santos and Brito (2012). Respondents were asked to chose, among five options, from 1 (below average) to 5 (above average) which best describes the firm overall average performance compared to those of competitors in terms of customers' and employees' satisfaction, social and environmental performance based on managers' perceptions. Subjective response on performance are reliable (Tan \& Litschert, 1994), and positively related to objective performance indicators (Richard et al., 2009; Wall et al., 2004).

\subsection{Procedure}

A web-based survey was combined with sending emails to respondents to participate in the study (Andrews et al. 2003). The authors used the "esurvey creator" software to collect data from respondents between June 2017 and November 2017. Respondents were allowed time to complete the questionnaires at their conveniences while they remain anonymous. In addition, voluntary participation was encouraged, and the respondents were informed that they were able to withdraw from the study at any stage if they wished to do so.

\subsection{Reliability/Validity test}

The authors used KMO, Bartlett's test and Cronbach's alpha to test the validity and reliability of the constructs. Cronbach alpha was used to determine the internal reliability 
of the items in the questionnaire. Cronbach alpha shows how well the items in a set in the questionnaire are positively correlated to one another (Sekaran \& Bougie, 2010). Cronbach's alpha for human resources (0.84), financial resources (0.72), strategic analysis capability (0.66), organisational structure (0.84), strategic performance (0.78) and the overall scale of 15 questions (0.72) indicates that the measurement instrument is reliable (Zikmund et al., 2013). Indeed, the questionnaire effectively measures the variables explored in this study. The KMO and Bartlett's test of sampling adequacy was significant (KMO; 0.664, $\mathrm{P}=0.000<0.05$ ) and well above the recommended 0.5 (Hair et al., 2010).

\subsection{Handling common method bias}

Following Conway and Lance (2010), this study was conducted at the firm level, the participants were analysts/supervisors, lower, middle and senior managers drawn from sales, marketing, finance/audit, customer service, and engineering departments of the sample firms head offices and eight regional offices across Nigeria. This group of employees are in the best position to provide reliable information on the subject. The validity tests performed on the constructs and their items showed that the established criteria were satisfied. The authors used a panel of six academic and non-academic experts' to review the questionnaire items in order to ascertain face validity, comprehensiveness and coherency. We reduced the evaluation apprehension by assuring to protect the respondent anonymity (Conway \& Lance, 2010; Podsakoff et al., 2003). These steps ensured that the effect of common method bias was minimal.

\subsection{Data analysis}

Descriptive statistics were used to provide a profile of respondents' demographics. Data frequency distribution was used in describing and explaining the respondents' characteristics. In this respect, the authors used fundamental statistical measures (frequencies, percentages). In the light of Wiersema \& Bowen, (2009), we used multiple regression and correlation analysis to analyse the relationship and strength of association between the variables. Hierarchical regression analysis was employed to test the moderating effect of organisational structure in the relationship between human resources, financial resources, strategic analysis capability and strategic performance. The hypotheses were tested at $0.05 \%$ significance level, with $95 \%$ confidence, which is acceptable in nonclinical research works. Statistical package for social sciences (SPSS 17) software is employed for the analyses conducted.

\section{Results}

120 questionnaires were administered to the respondents, 105 respondents completed and returned the questionnaires which account for $87.5 \%$ response rate. Bryman \& Bell (2015), Mugenda \& Mugenda (2009), suggest that a feedback rate of $50 \%$ is adequate for data analysis. In terms of the demographic profile of the respondents, the respondents were classified into four groups of age: between 25-34 years old; $35-44$ years old; $45-54$ years old; 55 years old and above. $36 \%$ of the respondent's age is between 25-34 years old. More than half $62 \%$ of the respondents were between 35-44 years old. About $2 \%$ were between 45-54 years old. There are no respondents whose age was 55 years and above. With respect to educational qualifications, $44 \%$ of the respondents have a first degree (HND/B.SC), $55 \%$ have a second degree (MBA/M.SC) and $2 \%$ have professional certifications. With regard to work experience in years, only $7.6 \%$ respondents had worked for the firms for less than five years. The results suggest that majority of the people who responded to the questionnaire had worked in the firms for 5 years and above $92.4 \%$. Furthermore, $2 \%$ of the respondents were directors, $10 \%$ were 
senior managers, $45 \%$ were middle managers, $41 \%$ were lower level managers, $2 \%$ were analysts and supervisors. The sample may be considered adequate in terms of the distributions of these characteristics.

Correlation results

The results in table 1, indicates that the association between human resources and strategic performance is positive and significant $(R=0.299$, $p$-value $=0.002)$. The relationship between financial resources and strategic performance is positive and statistically significant $(\mathrm{R}=0.415$, $\mathrm{p}$-value $=$ 0.000). Similarly, strategic analysis capability is positively and significantly related to strategic performance.

Table 1. Correlation results of the relationships between strategic performance, human resources, financial resources and strategic analysis capability

\begin{tabular}{|c|c|c|c|}
\hline & Human resources & Financial resources & $\begin{array}{c}\text { Strategic analysis } \\
\text { capability }\end{array}$ \\
\hline Pearson Correlation & $.299 * *$ & $.415 * *$ & $.222^{*}$ \\
\hline Sig (2 tailed). & .002 & .000 & .023 \\
\hline $\mathrm{N}$ & 105 & 105 & 105 \\
\hline
\end{tabular}

Source: Authors work.

** Correlation is significant at the 0.01 level (2- tailed)

* Correlation is significant at the 0.05 level (2- tailed)

The variance inflation factors value for all the models range between $1.412-4.193$ are less than 5 (Ringle et al., 2015), which means that multicollinearity does not exist. These results demonstrate good measurement properties of the model. Hierarchical regression analysis is appropriate to test moderating effects of variables (Sharma et al., 1981). In the hierarchical regression model, the independent variables (human resources, financial resources and strategic analysis capability) were inputted as block one. The interaction effects of the moderator (organizational structure) was inputted as block two. Presented in table 2 is the results of the hierarchical regression model.

Table 2. Hierarchical regression results of the moderating effect of organisational structure on the relationship between human resources and strategic performance

\begin{tabular}{|c|c|c|c|c|c|c|c|c|}
\hline & $\mathrm{R}$ & $\mathrm{R}^{2}$ & Adj. $\mathrm{R}^{2}$ & $\begin{array}{c}\text { Std } \\
\text { error }\end{array}$ & $\begin{array}{c}\mathrm{R}^{2} \\
\text { change }\end{array}$ & $\begin{array}{c}\mathrm{F} \\
\text { change }\end{array}$ & $\begin{array}{c}\text { Sig. F } \\
\text { change }\end{array}$ & VIF \\
\hline Model 1 & $.299 * *$ & .090 & .081 & .61930 & 0.90 & 10.135 & 0.002 & \\
\hline Model 2 & $.513^{* *}$ & .263 & .249 & .55979 & .174 & 24.062 & 0.000 & 2.619 \\
\hline
\end{tabular}

Source: Authors work.

Model 1: Human resources

Model 2: Interaction between human resources and organisational structure

$* *$ Correlation is significant at the 0.01 level (2- tailed)

Human resources have a significant and positive relationship with strategic performance $(R=0.299, p<0.05)$. The effect of the interaction term between human resources and organisational structure $(\mathrm{R}=.513, p<0.05)$ on strategic performance is significant. The results show that change in
$R^{2}$ is .174 , which indicates a $17.4 \%$ increase in the variation explained by the addition of the interaction term. Indeed, organisational structure does moderate the relationship between human resources and strategic performance. 
Table 3. Hierarchical regression results of the moderating effect of organisational structure on the relationship between financial resources and strategic performance

\begin{tabular}{|l|c|c|c|c|c|c|c|c|}
\hline & $\mathrm{R}$ & $\mathrm{R}^{2}$ & Adj. $\mathrm{R}^{2}$ & $\begin{array}{c}\text { Std } \\
\text { error }\end{array}$ & $\begin{array}{c}\mathrm{R}^{2} \\
\text { change }\end{array}$ & $\begin{array}{c}\mathrm{F} \\
\text { change }\end{array}$ & $\begin{array}{c}\text { Sig. F } \\
\text { change }\end{array}$ & VIF \\
\hline Model 1 & $.415^{* *}$ & .172 & .164 & .59060 & .172 & 21.398 & 0.000 & \\
\hline Model 2 & $.581^{* *}$ & .337 & .324 & .53103 & .165 & 25.404 & 0.000 & 1.944 \\
\hline
\end{tabular}

Source: Authors work.

Model 1: Financial resources

Model 2: Interaction between financial resources and organisational structure

**Correlation is significant at the 0.01 level (2- tailed)

Table 3 reveals that financial resources is positively and significantly related to strategic performance $(\mathrm{R}=0.415, \mathrm{p}<0.05)$. The effect of the interaction term between financial resources and organisational structure $(\mathrm{R}=.581, p<0.05)$ on strategic performance is significant. The results show that change in $R^{2}$ is .165 which indicates a $16.5 \%$ increase in the variation explained by the addition of the interaction term. Thus, organisational structure does improve the relationship between financial resources and strategic performance.

Table 4. Hierarchical regression results of the moderating effect of organisational structure on the the relationship between strategic analysis capability and strategic performance

\begin{tabular}{|l|c|c|c|c|c|c|c|c|}
\hline & $\mathrm{R}$ & $\mathrm{R}^{2}$ & Adj. $\mathrm{R}^{2}$ & $\begin{array}{c}\text { Std } \\
\text { error }\end{array}$ & $\begin{array}{c}\mathrm{R}^{2} \\
\text { change }\end{array}$ & $\begin{array}{c}\mathrm{F} \\
\text { change }\end{array}$ & $\begin{array}{c}\text { Sig. F } \\
\text { change }\end{array}$ & VIF \\
\hline Model 1 & $.222^{*}$ & .049 & .040 & .63287 & .049 & 5.335 & 0.023 & \\
\hline Model 2 & $.549^{* *}$ & .301 & .287 & .54528 & .252 & 36.749 & 0.000 & 1.412 \\
\hline
\end{tabular}

Source: Authors work.

Model 1: Strategic analysis capability

Model 2: Interaction between strategic analysis capability and organisational structure

**Correlation is significant at the 0.01 level (2- tailed)

* Correlation is significant at the 0.05 level (2-tailed)

Table 4 shows that strategic analysis capability is positively and significantly associated with strategic performance $(\mathrm{R}=$ $.222, \mathrm{p}<0.05)$. The effect of the interaction term between strategic analysis capability and organisational structure $(\mathrm{R}=.549, p<0.05)$ on strategic performance is significant. The results show that change in $R^{2}$ is .252 , which indicates a $25.2 \%$ increase in the variation explained by the addition of the interaction term. Thus, organisational structure does moderate the relationship between strategic analysis capability and strategic performance.

\subsection{Discussion}

Firms can efficiently use their human resources, financial resources and strategic analysis capabilities to adapt to dynamic business environment. All the six hypotheses examined are statistically significant at $5 \%$ level of significance. The results show that human resources have a positive and significant relationship with strategic performance. This finding lends support to the notion that human resource is a distinctive source of competitive advantage of the firms (Dunford et al., 2001). This result is consistent with the findings of (Langford \& Male, 2008; Lee et al., 2010; Ahmad \& Schroeder, 2003; Yuan-Yao et al., 2009; Sorooshian et al., 2010; Shigang \& Guozhi, 2016; Ologunde et al., 2015) that human 
resources have positive relationship with performance. We observed that firms achieve superior strategic performance when they optimize the skills, experience and competencies of their employees. Additional, firms with highly skilled employees can formulate and execute successful strategies that will have positive impact on strategic performance. Thus, H1 human resources positively and significantly influence mobile telecommunication firm strategic performance is supported. Financial resources have a positive and significant relationship with strategic performance. This result aligns with the findings of (Neneh, 2016; Shigang \& Guozhi, 2016; Othman et al., 2015, Aremu \& Oyinloye, 2014; Clarke et al., 2010) that financial resources/capability is positively related to performance. Firms can optimize their financial resources by acquiring other strategic assets and resources which can help them to achieve strategic objectives and performance. Top management commitment to efficient allocation and utilization of financial resources to secure the services of competent employees, acquire machines, equipments etc can enable a firm to implement new strategies, develop innovative products and services. Consequently, increase sales and strategic performance. Furthermore, availability of optimal working capital can enhance the firm's ability to settle its shortterm obligations as they fall due, facilitate the smooth running of the firm and thus, enhance strategic performance. Consistent with our expectation, $\boldsymbol{H} \mathbf{2}$, financial resources positively and significantly influence mobile telecommunication firm strategic performance is supported. Similarly, strategic analysis capability has a statistically significant positive relationship with strategic performance. This result affirms the studies of (Popoola, 2000; Karami, 2008; Okeke et al., 2016; Kumar 2015) who found that environmental analysis has significant and positive association with firm performance. Strategic analysis capability enables firms to assess opportunities and threats in their operating environment to improve strategic performance. Thus, H3, Strategic analysis capability is positively and significantly related to mobile telecommunication firm strategic performance is supported. These results lend support to the notion that firm resources and capabilities and understanding of their impacts are important determinant of strategic performance (Volna \& Papula, 2013). Organisational structure dictates how resources will be allocated in the organisation. The empirical result shows that organisational structure moderates the relationship between human resources and strategic performance. The interaction effect between human resources and strategic performance is statistically significant. The impact of human resources on strategic performance is stronger when firms adopt flexible structure and robust governance model that supports rapid decision making and empowers employees to use their initiatives. This finding support $\boldsymbol{H 4}$, organisational structure positively moderates the impact of human resources on strategic performance. In the same direction, organisational structure moderates the relationship between financial resources and strategic performance. The interaction effect between financial resources and strategic performance is statistically significant. The effect of financial resources on strategic performance is stronger when firms adopt flexible structure and robust governance model that supports the efficient allocation and utilization of financial resources. Strategic performance is enhanced when firms adopt flexible structure and appropriate governance model that support timely decision making on efficient allocation and use of the firm financial resources to achieve strategic objectives. Thus, $\boldsymbol{H 5}$, organisational structure positively moderates the impact of financial resources on strategic performance is supported. Furthermore, organisational structure moderates the relationship between strategic analysis capability and strategic performance. The interaction effect between strategic analysis capability and strategic 
performance is statistically significant. The impact of strategic analysis capability on strategic performance is stronger when firms adopt flexible structure and appropriate governance model that supports the use of robust strategic analysis tools to evaluate development in the firm business environment. Flexible organisational structure and governance model support timely decisions on how to use robust strategic analysis tools to assess and scan the firm's business environment, in order to adapt to rapidly changing environment. Therefore, H6, organisational structure positively moderates the impact of strategic analysis capability on strategic performance is supported.

\section{Conclusion}

In Nigerian mobile telecommunication sector, competent employees, availability of financial resources and strategic analysis capabilities are important to achieve superior strategic performance. Superior strategic performance can be achieved with the support of disciplined, hardworking, motivated managers and employees. Furthermore, efficient use of financial resources can contribute to firm strategic performance. Strategic performance can be sustained by building strategic analysis capability that enable firms assess the development in their business environment, leverage on the opportunities or cope with possible threats. The relationship between human resources, financial resources and strategic analysis capability are positively related to strategic performance. Additionally, the relationship between human resources, financial resources and strategic analysis capability and strategic performance is enhanced when organisational structure is added as a moderator. All the six hypotheses are statistically significant at 5\% level of significance. We conclude that human resources, financial resources and strategic analysis capability are important to achieved strategic performance. Additionally, a flexible organisational structure and governance model enhance strategic performance.

\subsection{Theoretical contribution}

The study adds to the strategic management literature by using RBV to examine the relationship between firm resources (human resources and financial resources), strategic analysis capability and strategic performance. Secondly, drawing on contingency theory, we identified one construct (organisational structure) that plays moderating role in the relationship between human resources, financial resources, strategic analysis capability and strategic performance of mobile telecommunication firms in the emerging market context, first of such attempt in the African contexts. Thus, this study makes a significant contribution to the RBV by providing a better understanding on the role specific tangible resources and capability play in achieving strategic performance. Additionally, the results of this study support the basic insight of the contingency theory that strategic performance depends on organisational characteristics such as organisational structure.

\subsection{Managerial implications}

The empirical results suggest that managers and executives should give close attention to their firm human resources, financial resources and strategic analysis capability. If firms are to achieve and sustain superior strategic performance, they need to adopt flexible organisational structure and governance model that supports efficient utilisation of firm resources and strategic analysis capability. By recognising the impact of organisational structure on human resources, financial resources and strategic analysis capability, managers/executives can significantly enhance strategic performance. On the other hand, if they give less attention to the importance of the role of organisational structure on human resources, financial resources and strategic analysis capability, 
firms may fail to achieve superior strategic performance. Finally, firms should adopt flexible organisational structure and governance model that supports efficient resources allocation and strategic analysis capability. Recognising these mechanisms provides support for improving strategic performance for firms.

\subsection{Limitations and future research}

The data used were collected from mobile telecommunication firms in Nigeria which limits the generalisation of these findings beyond this context. Future studies should explore other tangible, intangible resources and capabilities in other sectors such as manufacturing, financial institutions among others, and in other countries. The study used cross-sectional data, longitudinal data should be used to establish causal relationships between the constructs over time. We used subjective measure to operationalise strategic performance. Other researchers should use both objective and subjective measures to operationalize financial and strategic performance in a single study. Finally, further research should continue to search for variables mediating or moderating the relationship between firm resources, capabilities and performance. Despite the limitations, the applicability of this study adds to the literature as it relates to the strategic management and performance, provides interesting grounds for further debate and empirical research

Acknowledgment: The article received support from the Internal Grant Agency of FBE MENDELU (2018)

\section{References:}

Adema, K. L., \& Roehl, W. S. (2010). Environmental scanning the future event design. International Journal of Hospitality Management, 29, 199-207.

Adner, R., \& Helfat, C. E. (2003). Corporate effects and dynamic managerial capabilities. Strategic Management Journal, 24, 1011-1025.

Adomako, S., \& Danso, A. (2014). Financial Literacy and Firm performance: The moderating role of financial capital availability and resource flexibility. International Journal of Manangement and Organisational Studies, 3(4), 1-15.

Ahmad, S. \& Schroeder, R. (2003). The impact of human resource management practices ooperational performance: recognizing country and industry differences. Journal of Operations Management, 21(1), 19-43.

Ainuddin, R. A., Beamish, P. W., Hulland, J. S., \& Rouse, M. J. (2007). Resource attributes and firm performance in international joint ventures. Journal of World Business, 42, 47-60.

Akhigbe, A., \& Madura, J. (2008). Dividend policy and corporate performance. Journal of Business Finance \& Accounting, 23(9-10), 1267-1287.

Akinyele, S. (2011). Significance of strategic marketing to enterprise performance: An empirical analysis of Nigerian oil and gas industry. Global Journal of Management and Business Research, 10(6), 60-77.

Ambrose, M. L., \& Schminke, M. (2003). Organization Structure as a Moderator of the Relationship Between Procedural Justice, Interactional Justice, Perceived Organizational Support, and Supervisory Trust. Journal of Applied Psychology, 88(2), 295-305.

Andrews, D., Nonnecke, B., \& Preece, J. (2003). Electronic survey methodology: A case study in reaching hard to involve Internet Users. International Journal of Human-Computer Interaction, 16(2), 185-210. 
Aremu, M. A., \& Oyinloye, O. O. (2014). Relationship between strategic management and firms' performance in Nigerian banking industry. Kuwait Chapter of Arabian Journal of Business and Management Review, 4(3), 28-41.

Awino, Z. B. (2015). Organizational structure and performance of large manufacturing firms in Kenya: An empirical Investigation. Journal of Business and Economics, 6(11), 1883-1891.

Barney, J. B. (1991). Firm Resources and Sustained Competitive Advantage. Journal of Management, 17(1), 99-120.

Barney, J. B. (1986). Strategie factor markets: Expectations, luck and business strategy. Management Science, 10, 1231-1241.

Birkinshaw, J., Nobel, R. \& Ridderstrale, J. (2002). Knowledge as a contingency variable: do the characteristics of knowledge predict organization structure? Organization Science, 13, 274-289.

Bryman, A. (2004). Social Research Methods 2nd ed. Oxford: Oxford University Press.

Bryman, A., \& Bell, E. (2015). Business research methods, USA: Oxford University Press

Burns, T., \& Stalker, G. M. (1961). The Management of Innovation. London: Tavistock.

Chandler, A. D. (1962). Strategy and Structure: Chapters in the History of the Industrial Enterprises. Cambridge, MA: MIT Press.

Charreaux, G. (2005). Pour une gouvernance d'entreprise "comportementale": une réflexion exploratoire' [Toward a behavioural corporate governance theory: an exploratory view], Revue Française de Gestion, 31, 215-238.

Cheng, C. C. J., Yang, C. 1., \& Sheu, C. (2014). The link between eco-innovation and business performance: a Taiwanese industry context. Journal of Cleaner Production, 64, 81-90.

Clarke, M., Seng, D., \& Whiting, R. H. (2010). Intellectual Capital and Firm Performance in Australia. Working paper series no 12. Dunedin: Department of Accountancy and Business Law, University of Otago.

Conway, J. M., \& Lance, C. E. (2010). What reviewers should expect from authors regarding common method bias in organizational research. Journal of Business and Psychology, 25(3), 325-334.

Cooper, A. C., Gimeno-Gascon, F. J., \& Woo, C. Y. (1994). Initial human and financial capital as predictors of new venture performance. Journal of Business Venturing, 9(5), 371-395

Cyert, R. M., \& March, J. G. (1963/1992). Behavioral theory of the firm 2nd ed. Cambridge, MA: Blackwell Publishing Ltd.

Damanpour, F. (2010). An integration of research findings of effects of firm size and market competition on product and process innovations. British Journal of Management, 21, 9961010 .

Danso, A., \& Adomako, S. (2014). The financing behaviour of firms and financial crisis. Managerial Finance, 40(12), 1159-1174.

Datta, D. K., Guthrie, J. P., \& Wright, P. M. (2005). Human resource management and labour productivity: Does industry matter? Academy of Management Journal, 48(1), 135-145.

Demo, G. Neiva, E. R., Nunes, I., \& Rozzett, K. (2012). Human resources management policies and practices scale (HRMPPS): exploratory and confirmatory factor. Brazilian Administration Review, 9(4), 395-420. 
Dollinger, M. J. (1999). Entrepreneurship: strategies and resources. Upper Saddle River, NJ: Prentice Hall.

Dunford, B., Snell, S., \& Wright, P. (2001). Human resources and the resource-based view of the firm. Journal of Management, 27(6), 701-721.

Evans, N., Campbell, D., \& Stonehouse, G. (2003). Strategic management for travel and tourism. USA: Elsevier Butterworth Heinemann.

Grant, R. M. (1991). The resource-based theory of competitive advantage: Implications for strategy formulation. California Management Review, 23, 291-374.

Hair, J., Black, W., Babin, B., \& Anderson, R. (2010). Multivariate data analysis 7th ed. Englewood Cliffs: Prentice Hall.

Huselid, M. A. (1995). The impact of human resource management practices on turnover, productivity, and corporate financial performance. Academy of Management Journal, 3(38), $635-72$

Inmyxai, S., \& Takahashi, Y. (2010). The Effect of Firm Resources on Business Performance of Male- and Female-Headed Firms in the Case of Lao MSMEs. International Journal of Business and Information, 5(1), 63-90.

Kamoche, K. (1996). Strategic human resource management within a resource- capability view of the firm. Journal of Management Studies, 2(33), 213-233.

Karami, A. (2008). An investigation on environmental scanning and growth strategy in high tech small and medium sized enterprises: paper read at the high technology firms conference held at the between 21 and 23 May (stránky 1-17). Twente: University of Twente.

Kumar, P. (2015). Correlation Between Strategic Planning and Firm Performance. International Journal of Management \& Business studies, 5(2), 64-75.

Langford, D., \& Male, S. (2008). Strategic management in construction. Oxford: Blackwell Science.

Lawrence, P. R., \& Lorsch, J. W. (1967). Organization and Environment. Boston, MA: Harvard Business Press.

Lee, F., Lee, T., \& Wu, W. (2010). The relationship.between human resource management practices, business strategy and firm performance: evidence from steel industry in Taiwan. The International Journal Human Resource Management, 21(9), 1351-1372.

McDaniel, C., Lamb, C. W. \& Hair, J. F. (2008). Introduction to marketing", 9 $9^{\text {th }}$ ed. Australia, Thompson South-Western.

Morgan, N.A., Kaleka, A., \& Katsikeas, C. S. (2004). Antecedents of export venture performance: A theoretical model and empirical assessment. Journal of Marketing, 68, 90108.

Mousa, F. (2009). When do slack resources impact new venture success? PHD Thesis. USA: Washington State University.

Mugenda, O. M., \& Mugenda A. G. (2009). Research methods: Quantitative and Qualitative approaches, Nairobi: ACTS.

Muogbo, U. S. (2013). The impact of strategic human resource management on small and medium sized enterprises: A study of some selected paint manufacturing firms in Anambra State, Nigeria. Global Journal of Management and Business Studies, 3(3), 323-340. 
Neneh, B. N. (2016). Performance implications of financial capital availability on the financial literacy performance nexus in South Africa. Investment Management and Financial Innovations, 13(2-2), 354-362.

Nicholson, G. J., \& Kiel, G. C. (2003). Toward an integrative theory of boards of directors: the intellectual capital of the board. Paper presented at the Annual Meeting of the Academy of Management: Democracy in a Knowledge Economy, 1-6 August, Seattle, Washington.

Nigerian Communications Commission (2017). Retrieved form http://www.ncc.gov.ng/ stakeholder/statistics-reports/industry-overview\#view-graphs-tables-7

Nwachukwu, C., \& Chladkova, H. (2017). Human resource management practices and employee satisfaction in microfinance banks in Nigeria. Trends Economics and Management, 28(1), 2335 .

Nwachukwu, C., Chladkova, H., \& Olatunji, F. (2018). Strategy formulation process and innovation performance nexus. International Journal for Quality Research, 12(1), 147-164.

Nwosu, H. E. (2015). Effect of strategic planning on organizational performance: A study of selected brewing firms in Nigeria. The International Journal Of Business \& Management, 3(2), 162- 186.

Okeke, M. N., Onuorah, A. N., \& Jakpa, U. (2016). Impact of strategic management on the performance of small and medium scale enterprises (SMEs) in Nigeria: A study of selected SMEs in Delta State. Global Journal of Applied, Management and Social Sciences, 11, 57-66.

Ologunde, A. S., Monday, J. U., \& James-Unam, F. C. (2015). The impact of strategic human resource management on competitiveness of small and medium scale enterprises in the Nigerian hospitality industry. African Research Review, 9(4), 264-276.

Othman, R., Arshad, R., Abdul Aris, N., \& Mohd Arif, S. M. (2015). Organizational resources and sustained competitive advantage of cooperative organizations in Malaysia. Procedia Social and Behavioral Sciences, 170, 120-127.

Oyewobi, A. O., Windapo, K., \& Rotimi, J. O. (2013). Impact of organizational structure and strategies on construction organizations performance. South Africa, Newzealand: University of Cape Town and Auckland University of Technology, New Zealand.

Pantzalis, C. (2001). Does location matter? An empirical analysis of geographic scope and MNC market valuation. Journal of International Business Studies, 32, 133-155.

Pearce II, J. A., \& Robinson Jr, R. B. (2011). Strategic management: formulation, Implementation, and control. 12th ed. Boston, MA: McGraw-Hill Irwin.

Podsakoff, P. M., MacKenzie, S. M., Lee, J., \& Podsakoff, N. P. (2003). Common method variance in behavioral research: a critical review of the literature and recommended remedies. Journal of Applied Psychology, 88(5), 879-903.

Popoola, S. O. (2000). Scanning the environment for competitive advantage: a study of corporate banking managers in Nigeria. Libri, 50, 210-216.

Pugh, D. S., Hickson, D. J., Hinings, C. R., \& Turner, C. (1969). The context of organisational structures. Administrative Science Quarterly, 14, 91-114.

Qingmin, K., Helmut, N., \& Juegen, D. (2012). Managing beyond the factory walls: Effects of four types of strategic integration on manufacturing plant performance. Journal of Operations Management, 24, 148-164.

Richard, P. J., Devinney, T. M., Yip, G. S., \& Johnson, G. (2009). Measuring organisational performance: towards methodological best practice. Journal of Management, 35(3),718-804. 
Ringle, C. M., Wende, S \& Becker, J-M. (2015). SmartPLS 3. Bönningstedt: SmartPLS. Retrieved from http://www.smartpls.com

Robbin, S. P., \& DeCenzo, D. A. (2005). Fundamentals of management: Essential Concepts and Applications. Upper Saddle River, NJ: Prentice Hall.

Rose, R. C., \& Kumar, N. (2007). Blockade for career advancement in Japanese organization abroad: The case of Malaysian subsidiaries. American Journal of Applied Sciences, 4(1), 813.

Santos, J. B., \& Brito, L. A. (2012). Toward a subjective measurement model for firm performance. Brazilian Administrative Review, 96, 95-117.

Sekaran, U., \& Bougie, R. (2010). Research Methods for Business: A Skill-Building Approach", $5^{\text {th }}$ ed. New Jersey: John Wiley and Sons.

Sharma, S., Durand, R. M., \& Gur-Arie, O. (1981). Identification and analysis of moderator variables. Journal of Marketing Research, 18, 291-300.

Shigang, Y., \& Guozhi, L. (2016). An empirical study of core capability and international performance for construction firms in China. International Journal of Business and Social Science, 7(9), 197-204.

Sorooshian, S., Norzima, Z., Yusof, I., \& Rosnah, Y. (2010). Effect analysis on strategy implementation drivers. World Applied Sciences Journal, 11(10), 1255-1261.

Stefanović, M., Tadic, D., Arsovski, S., Pravdic, P., Abadić, N., \& Stefanović, N. (2015). Determination of the effectiveness of the realization of enterprise business objectives and improvement strategies in an uncertain environment. Expert Systems, 32(4), 494-506. doi: 10.1111/exsy. 12102

Tan, J. J., \& Litschert, R. J. (1994). Environment-strategy relationship and its performance implications: An empirical study of the Chinese electronics industry. Strategic Management Journal, 15(1), 1-20.

Teece, D. J., Pisano, G., \& Shuen, A. (1997). Dynamic capabilities and strategic management. Strategic Management Journal, 18(7), 509-533.

Terziovski, M. (2010). Innovation practice and its performance implications in small and medium enterprises (SMEs) in the manufacturing sector: a resource-based view. Strategic Management Journal, 31, 892-902.

Volna, J., \& Papula, J. (2013). Analysis of the behavior of Slovak enterprises in the context of low innovation performance. Procedia- Social and Behavioral Sciences, 99, 600-608.

Wall, T. D., Michie, J., Patterson, M., Wood, S. J., Sheeran, M., Clegg, C. H., \& West, M. (2004). On the validity of subjective measures of company performance. Personnel Psychology, 57(1), 95-118.

Wang, C. H. (2014). A longitudinal study of innovation competence and quality management on firm performance. Innovation: Management, Policy \& Practice, 16, 392-403.

Wernerfelt, B. (1984). A resource-based view of the Firm. Strategic Management Journal, 5, 171-180.

Wiersema, M. F., \& Bowen, H. P. (2009). The use of limited dependent variable techniques in strategy research: issues \& methods. Strategic Management Journal, 30(6), 679-692.

Woodward, J. (1965). Industrial Organization, Theory and Practice. Oxford: Oxford University Press.

Yuan-Yao, F., Wei-Hwa, P., Yueh-Chuen, H., \& Yan-Kwang, C. (2009). The Effects of Firms 
Resources and Capabilities on its Performance of IC Design Industry in Taiwan. Information Technology Journal, 8, 688-697.

Zikmund, W. G., Babin, B. J., Carr, J. C., \& Griffin, M. (2013). Business research methods 9th ed. USA: South-Western, Cengage Learning.

\section{Chijioke Nwachukwu}

Mendel University in Brno,

Brno,

Czech Republic

cesogwa@yahoo.com

\section{Helena Chladkova}

Mendel University in Brno,

Brno,

Czech Republic

chlad@mendelu.cz 


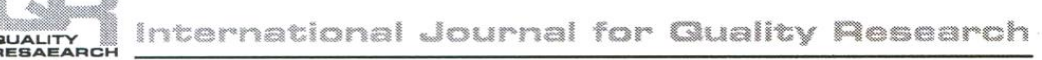

